\title{
Száz éve hunyt el Bókay Árpád (1856-1919)
}

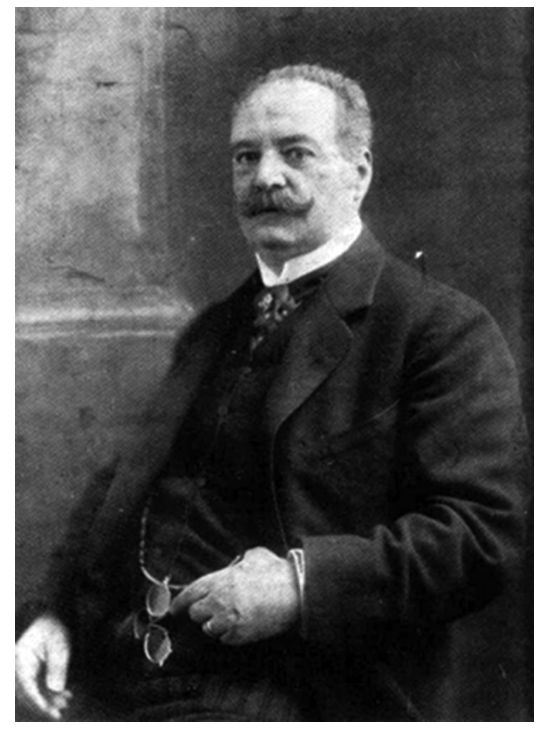

Dr. Bókay Árpád orvosprofesszor (1856-1919)

Dr. Bókay Árpád orvosprofesszor korának egyik jeles személyisége volt [1]. Neves orvosdinasztia tagja. Szakmai munkássága és közéleti szereplése révén kivívta korának és az utókornak is a megbecsülését. Az Országos Biológiaverseny napjainkban is az ő nevét viseli [2]. Ugyanezt bizonyítja, hogy a Bókaytelep nevü, XVIII. kerületi (pestszentlőrinci) városrész névadója. A Bókaykert mindennap a lakosság rendelkezésére áll 6-tól 22 óráig. Naponta több százan, míg hétvégeken ezrek keresik fel pihenés és szórakozás céljával. Pestszentlörincnek a legnagyobb üdülőövezete, mely az ott lakók kedvenc

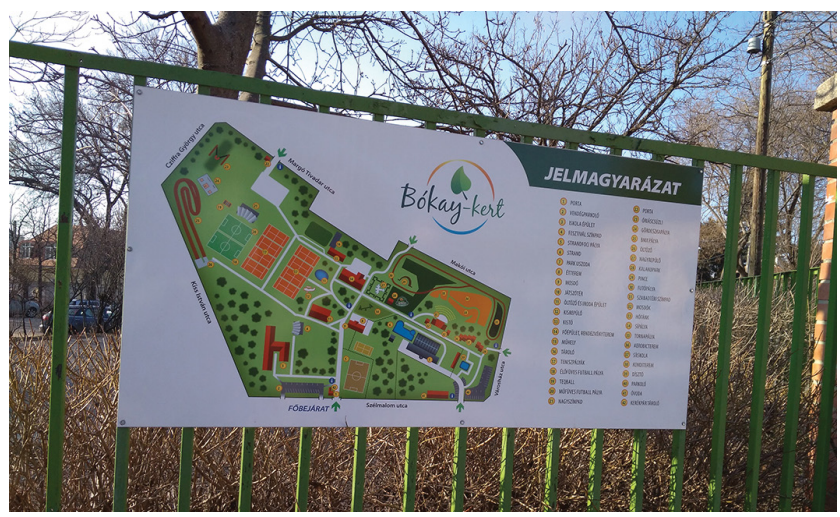

1. ábra

A Bókay-kert vázlatos térképe a Bókay-kert bejárati kapujánál Budapesten, a XVIII. kerületben sétálóhelyévé vált az elmúlt száz esztendő folyamán (1. ábra). A Bókay-kertben egy szobra található.

Ez a városrész Bókay Árpád professzor tulajdona volt, melyet felparcelláztatott, s egyes területeket közhasználatra (például iskolaépítésre, templomépítésre) engedett át. A Bókay-kert szomszédságában húzódik a Bókay Árpád utca (2. ábra).

A Bókay Árpád Általános Iskolában (3. ábra) - 1181 Budapest, Wlassics Gyula utca 69. - 1902-ben kezdődött meg a tanítás; az intézményben emléktáblán örökítették

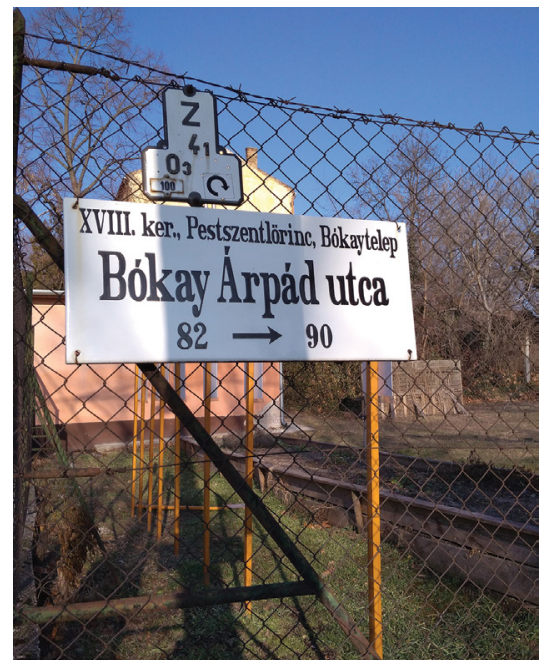

2. ábra A Bókay Árpád utca a Bókay-kert mellett, Budapesten, a XVIII. kerületben

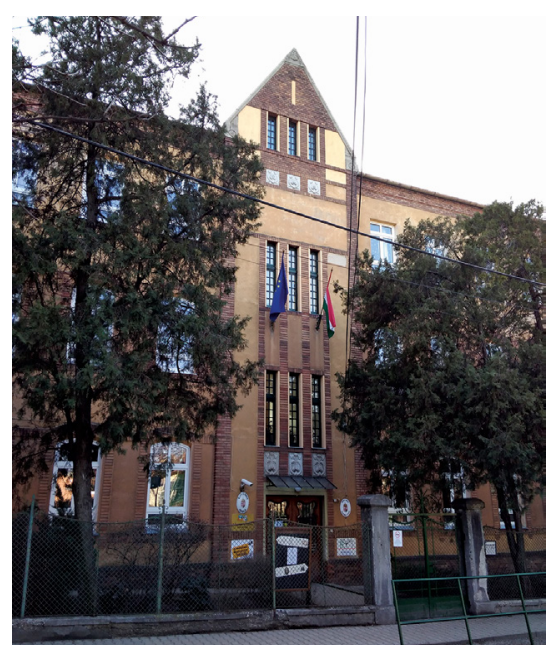

3. ábra XVIII kerïlet, Wlassics Gyula u. 69.) 
meg a nevét. Pestszentlőrinc-Pestszentimre is támogatta 2003-ban annak az emlékiratnak a kiadását, amely Bókay Árpád gyermek- és ifjúkori gazdag élményvilágába enged betekintést 1883-ig, kolozsvári múködése kezdetéig [3]. Sajnos, az emlékirat e dátummal véget ér.

Bókay Árpád értelmiségi családból származott. Atyja, id. Bókay János (1822-1884; eredeti nevén Bock) nagyhírü gyermekorvos, korának mint ember és tudós egyaránt kimagasló alakja; öccse, ifj. Bókay János (18581937) gyermekgyógyász, egyetemi tanár, az MTA levelező tagja lett. Bókay Árpád Pesten született, 1856. augusztus 15-én. Már orvostanhallgató korában HoppeSeyler (1825-1895) laboratóriumában dolgozott. Oklevelet 1879. november 29-én szerzett, de már korábban, 1878-ban Korányi Frigyes (1828-1913) oldalán gyakornok, 1879-ben Balogh Kálmán (1835-1888) mellett a gyógyszertani és általános kórtani tanszék tanársegéde lett. 1883 és 1890 között a kolozsvári egyetemen az általános kór-, gyógytan és gyógyszertan nyilvános rendes tanára. Az Erdélyi Múzeum-Egyesület lapjában - a kísérletei alapján - a 'methaemoglobinról' publikál egy rendkívül színvonalas tudományos cikket [4]. Balogh Kálmán halála után, 1890-től a budapesti egyetemen a gyógyszertan tanára. A Magyar Tudományos Akadémia 1896ban levelező tagjává választotta. 1897. április 11-én nemességet, családi címert és a „bókai” nemesi előnevet szerezte meg. Az Országos Balneológiái Egyesület alelnöke, majd elnöke. 1905-től a Budapesti Orvosegyesület elnöke. A budapesti Orient szabadkőmúves páholy tagja 1902-tôl, majd 1915-től a magyarországi páholyok nagymestere. Alapelvét is mint a szabadkőmúvesek nagymestere fogalmazta meg székfoglaló beszédében [5]: „Minden anya, aki szül, külön megbecsülés és tisztelet tárgya legyen mindenki előtt. A többször szülő anyáknak kellene érdemjeleket osztogatni, s annál nagyobbat, annál fényesebbet, minél több gyermeket tudnak nemcsak szülni, hanem bizonyos korig fel is nevelni."

Ezen alapelv teljesült családi életében is. Feleségül vette Herrich Károly (1818-1888) miniszteri tanácsos lányát, Herrich Szidóniát (1863-1946). Házasságukból több gyermek született: bókai dr. Bókay Zoltán (18851955) gyermekorvos, a Debreceni Egyetem Gyermekklinikájának igazgatója; bókai Bókay Nadine (18871957), férje verebélyi dr. Verebély Tibor (1875-1941), orvosdoktor, egyetemi tanár; bókai Bókay Judit (18921980), férje verebélyi Verebély László (1883-1959), műegyetemi tanár, az MTA levelező tagja volt. Testvére bókai Bókai János (1858-1937) gyermekgyógyász, egyetemi tanár, az MTA levelező tagja volt.

A gyógyszertan, az élettan világhírü professzora. Elsősorban a gyomornedv-elválasztásra gyakorolt gyógyszertani hatásokkal, a gyógyszermérgezésekkel foglalkozott. Alapvetőek toxikológiai és balneológiai kutatásai, vezető szerepet játszott Budapest modern kori fürdőintézményrendszerének kialakításában.

1891-ben megalapítja a „Magyar Orvosi Archivumot”, amelyet anyagi áldozatokkal éveken át támogat, csak hogy legyen hol megszólalniuk az egyre szaporodó elméleti kutatóknak; 1894-ben Kétly és Korányi profeszszorokkal megindítja és szerkeszti éveken át a nagy „Belgyógyászat kézikönypét”, s oroszlánrésze volt az 1909-ben megjelent III. kiadású Magyar gyógyszerkönyv szerkesztésében. 1894 és 1911 között többekkel az Ungarisches Archiv für Medizin szerkesztője.

1919. március 28-án a Tanácsköztársaság Közoktatásügyi Népbiztossága az állásából felfüggesztette. Elhunyt Budapesten, 1919. október 20-án.

$\mathrm{Az}$ áhítat csendje átváltott a döbbenet csendjére! 63 évesen meghalni a XX. század elején - egészséges embernek - nem szokványos eset. Miért? Bókay Árpádnak az értelmes gondolkodás alkotó ereje volt életének értelme. Az aktuális problémákat komoly alapra helyezve nemcsak elgondolta, de a tervezést végigvitte, és elképzeléseit megvalósította.

Éppen alkotó élete csúcsán érte a proletárdiktatúra, amely tönkretett minden alkotást, eszmét és tudást.

A jelenben, az orvostörténeti kutatásokban is a békebeli élet már csak nyomokban létező szakmai múltjába, szakadozó és időhézagokkal lehet betekintést nyerni, és akkor kitárul az a kontrasztos világkép, amely ennek a mélységében lapul.

Amit - Bókay Árpád akadémikus - évtizedekig épített, egy konszolidált világ kultúrájában, azt romba döntötték. Megfosztották munkájától, betöltött funkcióitól, társadalmi személyes presztízsétől. Mint minden alkotót, akit kisemmiztek, akit földönfutóvá tettek - azt ép ésszel nehéz elviselni. Ezt bizonyítja, hogy a társadalmi stressz átalakult, olyan súlyos lelki stresszé, hogy vélhetően annak az elviselhetetlenségébe - belehalt.

Emlékét az utókor tisztelete övezi.

\section{Irodalom}

[1] Vámossy Z. Árpád Bókay (1856-1919). [Bókay Árpád (18561919).] Orv Hetil. 1919; 63: 383-384. [Hungarian]

[2] Vincze J. Árpád Bókay. In: Vincze J. (ed.) We remember our physicians, 29. [Bókay Árpád. In: Vincze J. (szerk.) Emlékezünk orvosainkra 29.] NDP Kiadó, Budapest, 2016; pp. 287-288. [Hungarian]

[3] Buza P. (ed.) This Bókay seems to be an intelligent man! Illustrious doctor from the ancient Pest. [Ez a Bókay, úgy látszik, intelligens ember! Egy jeles orvos a régi Pestról.] Száz Magyar Falu Könyvesháza Kht., Budapest, 2003. [Hungarian]

[4] Bókai Á. Does methaemoglobin formed in living blood under chloric acid cali poisoning? [Képződik-é methaemoglobin az élő vérben chlorsavas kali mérgezésnél?] Orv Természettud Ért. 1887; 9: 1-7. [Hungarian]

[5] Bókay Á. Path, life and truth, inaugural of grand-master of Hungarian free-masons. [Az út, az élet, az igazság. A magyarországi szabadkömúvesek nagymesterének székfoglaló beszéde.] Budapest, 1915. [Hungarian] 